\title{
63. "Spreading" the word: Contagion as method in adaptations of plague narratives
}

\section{Burcu KAYIŞCI AKKOYUN'}

APA: Kayışcı Akkoyun, B. (2021). "Spreading" the word: Contagion as method in adaptations of plague narratives. RumeliDE Dil ve Edebiyat Araştırmaları Dergisi, (24), 1113-1123. DOI: 10.29000/rumelide.995498.

\begin{abstract}
Plagues have both infected physical bodies as bacterial and viral epidemics and permeated textual bodies starting from ancient and biblical texts throughout history. This paper will explore the plague as portrayed in Daniel Defoe's fictional testimony A Journal of the Plague Year (1722) and Mark Ravenhill's libretto of his music theatre Ten Plagues (2011). Defoe brings together poignant fictional stories about the plague victims and survivors with the statistical reports quoted, and at times analysed, by his narrator to portray the Great Plague of London that hit the city in 1665. Ten Plagues is a stage adaptation of $A$ Journal of the Plague Year. Drawing upon the textual dynamics of the plague or "the outbreak narrative" in Priscilla Wald's terms (2008) and Linda Hutcheon's understanding of adaptation as a palimpsest (2006), this paper argues that the idea of contagion could operate not only as subject matter or a narrative thread but also as a method or medium as demonstrated by these two works. The interwoven stories of A Journal and Ten Plagues represent survival and resilience along with the fragile and precarious condition of humanity under medical and social uncertainties. The paper concludes that Defoe and Ravenhill lead their audience to contemplate on "diseased" pasts and futures by envisioning isolation and connection in dire times and establish the power of art and fiction in the aesthetic and critical space they create together.
\end{abstract}

Keywords: Plague, contagion, adaptation, Defoe, Ravenhill

\section{Sözü “yaymak:” Salgın anlatılarının uyarlamalarında bir metod olarak bulaşım}

$\ddot{\mathbf{O z}}$

Salgın hastalıklar tarih boyunca hem bakteri ve virus kaynaklı epidemiler şeklinde fiziksel bedenlere bulaşmış hem de klasik dönem anlatıları ve İncil'deki hikayelerden başlayarak aynı zamanda metinsel düzleme sirayet etmiştir. Bu makale, Daniel Defoe’nun Türkçe'ye Veba Yılı Günlüğü olarak çevrilmiş, 1722 tarihli kurgusal tanıklık anlatısı A Journal of the Plague Year ile Mark Ravenhill'in müzik tiyatrosu Ten Plagues için 2011 yılında yazdığı librettoyu inceleyecektir. Defoe, salgın kurbanları ve geride kalanların dokunaklı hikayeleriyle, anlatıcısının alıntıladığı ve zaman zaman değerlendirdiği istatistiksel bilgileri bir araya getirerek 1665 yılında Londra'yı perişan eden Büyük Veba Salgını'nı anlatır. Ten Plagues, A Journal of the Plague Year'in sahne uyarlamasıdır. Bu makale, Priscilla Wald'un (2008) deyimiyle "salgın anlatısı"'nın metinsel dinamiklerinden ve Linda Hutcheon'ın (2006) "bir palimpsest olarak uyarlama" yaklaşımından yola çıkarak, bu iki eserde görüldüğü üzere bulaşım fikrine yalnızca konu ve izlek olarak değil, bir yöntem ya da araç olarak da yaklaşılabileceğini iddia eder. A Journal ve Ten Plagues’in girift hikayeleri insanlığın tıbbi ve sosyal belirsizlikler karşısındaki kırılgan ve tehlikeli durumunun yanı sıra hayatta kalışını ve dirayetini temsil eder. Sonuç

Dr. Öğr. Üyesi, Boğaziçi Üniversitesi, Fen Edebiyat Fakültesi, Batı Dilleri ve Edebiyatları (İstanbul, Türkiye), burcu.akkoyun@boun.edu.tr, ORCID ID: 0ooo-0001-6752-8676 [Araştırma makalesi, Makale kayıt tarihi: 11.08.2021kabul tarihi: 20.09.2021; DOI: 10.29000/rumelide.995498]

Adres $\mid$ Address

RumeliDE Dil ve Edebiyat Araşturmalar Dergisi $\quad$ RumeliDE Journal of Language and Literature Studies Osmanağa Mahallesi, Mürver Çiçeği Sokak, No:14/8 $\quad$ Osmanağa Mahallesi, Mürver Çiçeği Sokak, No:14/8

Kadıköy - İSTANBUL / TÜRKIYE 34714 Kadıköy - ISTANBUL / TURKEY 34714 e-posta: editor@rumelide.com e-mail: editor@rumelide.com, tel: +90 505 7958124, +90 2167730616 phone: +90 505 7958124, +90 2167730616 
olarak makale, Defoe ve Ravenhill'in zor zamanlarda tecrit ve yakınlığı tahayyül ederek okur ve izleyicilerini salgın hastalıklarla dolu geçmiş ve gelecek hakkında düşünmeye davet ettiklerini ve birlikte yarattıkları estetik ve eleştirel düzlemde sanatın ve kurgunun gücünü gösterdiklerini öne sürer.

Anahtar kelimeler: Salgın, bulaşım, uyarlama, Defoe, Ravenhill

\section{Introduction}

Plagues have always played a major role in history not only by causing the death of millions worldwide in viral and bacterial epidemics but also by haunting, infecting, and shaping human imagination and artistic expression in textual bodies starting from ancient and biblical texts. Whether they are represented literally with the real symptoms, experience, and the aftermath of diseases or are employed as metaphors for socio-political or moral corruption, plagues permeate narratives across different genres ranging from medical and historical accounts to literary narratives. The idea of the plague, which could be grasped only as liminality at a particular moment, generates a deep sense of crisis, intensifies the fear of the unknown, and shakes, if not shatters, the very foundations of a society by overturning existing rules and structures. In addition to their tangible and measurable consequences such as "demographic pressure" in social and economic spheres, plagues thus also have deep spiritual and intellectual impact: disease "has channeled (or blocked) individual creativity, and it may on occasion have set its stamp on the 'optimism' or 'pessimism' of an entire age" (Hays, 2009, p.2). When plagues become the embodiment of divine retribution as in classical or sacred texts or are considered so in later examples, they lead humans to contemplate on the nature of evil and sin as well as on human fragility and the possibility of redemption.

Each disease affects individuals and society in different ways as their specific epidemiology would indicate. Their discursive aspects, however, are equally important to understanding social and historical repercussions of diseases. In other words, "epidemics are also themselves intellectual 'constructs' which, once formulated, have a history, vitality and resilience of their own" (Slack, 1992, p. 8). This vitality and resilience is clearly visible in the realm of literature, which is the primary focus of this paper. While pointing out that the plague is "older than literature" since "it is present in myth and ritual in the entire world," Rene Girard (1974) stressed its prevalence by stating that it is found "everywhere in literature" (p. 833). As Girard observed, the earliest occurrence of the theme can be traced back to the first example of Western literature: Homer's Iliad. It opens with the outbreak of a plague among the Achaeans, which is sent by Apollo to punish Agamemnon for abducting Priest Chryses's daughter and ignoring the father's pleas: "for he, enraged by the king, / spread a foul plague through the army, and men were dying, / all because Chrysds his priest had been dishonoured/ by Atreus's son." (ca. $8^{\text {th }}$ century BC./2015, p.25). Other seminal texts that compose what may be called a "plague-ridden" literary canon are Sophocles' Oedipus Rex (ca. 429 BC), Lucretius' On the Nature of Things (55 BC), Boccaccio's Decameron (13491353), Defoe's A Journal of the Plague Year (1722), Mary Shelley's The Last Man (1826), Thomas Mann's Death in Venice (1912), Karel Čapek's The White Plague (1937), and Albert Camus's The Plague (1947)2.

2 Emrah Atasoy's 2020 article "Spekülatif Kurguda Salgın Teması" (Ankara Üniversitesi Dil ve Tarih-Coğrafya Fakültesi Dergisi, 6o(2), 672-685. doi:http://dx.doi.org/10.33171/dtcfjournal.2020.60.2.9) provides an overview of the theme but with a specific focus on speculative genres such as science fiction, dystopian writing, and (post)apocalyptic literature and cinema.

RumeliDE Dil ve Edebiyat Araştrmalarl Dergisi Osmanağa Mahallesi, Mürver Çiçeği Sokak, No:14/8 Kadıköy - İSTANBUL / TÜRKIYE 34714 e-posta: editor@rumelide.com tel: +90 $5057958124,+902167730616$
Address

RumeliDE Journal of Language and Literature Studies Osmanağa Mahallesi, Mürver Çiçeği Sokak, No:14/8

Kadıköy - ISTANBUL / TURKEY 34714

e-mail: editor@rumelide.com,

phone: +90 5057958124 , +90 2167730616 
Fictional accounts that communicate the emergence, journey and impact of the diseases usually contain horrifying images of infected bodies and portray the strict measures taken by authorities to fight the plagues as well as the gradual collapse of social order. They are imbued with fear and despair, yet at times they convey a glimmer of hope arising from fostering a sense of community and providing future generations with 'vital' information. In fact, plagues could even be conspicuous by their absence in the literary narratives produced during or following their sway. In her compelling analysis on modernism, the influenza pandemic, and the interwar literature, Elizabeth Outka (2019) argued that while the traumatic experience of the world war and the losses caused by it are at the centre of historical and literary accounts, modernist literature simultaneously and inevitably represented "the pandemic's spectral presence" that seeped "into memories, poems, and novels" although it was "left out of written histories" (p. 3). As Outka explicated, the prominent examples of literary modernism such as Woolf's Mrs. Dalloway, Eliot's The Waste Land, and Yeats's "The Second Coming" thus conveniently lend themselves to be reread through "the lens of the pandemic" (p. 3), which reveals different interpretative possibilities within the texts.

This paper also engages with the hermeneutical potential engendered by the depiction of the plague, but with a wider temporal scale as it examines two texts written almost 300 years apart: Daniel Defoe's fictional eyewitness account A Journal of the Plague Year (1722) and Mark Ravenhill's libretto of his song cycle Ten Plagues (2011). A song cycle is a group of songs each of which "is closed in itself, and can be outwardly distinguished from the others. ...but all have an inner relationship to one another, because one and the same idea runs through all of them (von Dommer, 1860, as cited in Tunbridge, 2010, p. 6). Ravenhill's song cycle is mainly an adaptation of $A$ Journal, and another source of inspiration is clearly the Book of Exodus, which tells the biblical story of the Ten Plagues inflicted by God on the Egyptians when Pharaoh refused to free the enslaved Israelites. The plagues include water turning into blood, the Nile teeming with frogs, lice coming upon men and animals, livestock pestilence, thunderstorm of hail and fire, and the death of every firstborn son in Egypt. As this clear biblical reference suggests, much as these two texts apparently respond to the epidemiological and socio-cultural context of their own time, they are also in dialogue with a larger collective experience and imaginative repertoire, perhaps even more so today in the face of the Covid pandemic. Therefore, "contagion" on a figurative as well as a literal level is the departure point for this paper.

A brief look at the etymology of the words "plague" and "contagion" will shed light on the following analysis. "Plague," or plaga in Greek and Latin, literally means a "blow," "stroke," or "wound" (Sontag, 1989, p. 44; DeWall, 2011, p. 137). The original meaning of the word is suggestive of the unpredictable pace of diseases and the speed of infection that usually leaves wounds where it touches, which leads to the similarly loaded meaning of the second word. "Contagion" is derived from the Latin word contagio: the combination of the prefix con- (together, with) and the word tangere (to touch) (Wald, 2008, p. 12; Mitchell, 2012, p. 44). Considering the etymology of the word "contagion," this paper argues that the idea of contagion, if not the plague, could operate not only as subject matter or a narrative thread but also as a method or medium in A Journal of the Plague Year (1722) and Ten Plagues (2011). The narrative layers in which these two texts "touch" each other will be explored to illustrate how they together represent survival and resilience along with the fragile and precarious condition of humanity under medical and social uncertainties. The introduction will be followed by the discussion of two texts within the framework of plague narratives and their textual dynamics along with Hutcheon's theory of adaptation. The paper will conclude that fiction and storytelling across genres as employed by Defoe and Ravenhill could be as powerful as factual information in/for difficult times. The two authors imagine solitude and solidarity, and lead their audience to contemplate on "diseased" pasts and futures in their

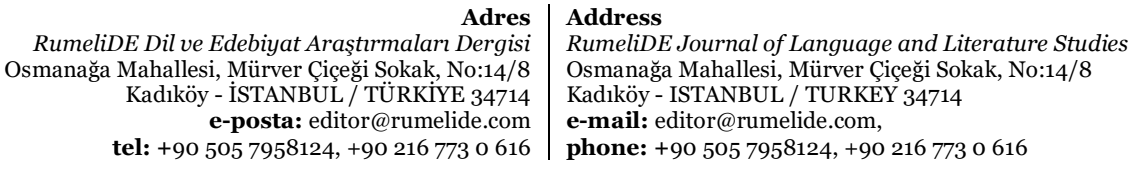


palimpsestic interaction. The severity of the Covid outbreak that has caused millions of deaths and made many more suffer worldwide testifies to the urgency of this endeavour.

\section{Textual dynamics of plague narratives and A Journal of the Plague Year}

Referring to the literal meaning of "contagion" mentioned above, Priscilla Wald (2008) explained that the word was used as early as the fourteenth century in reference to the circulation of ideas and attitudes. In later medical contexts, "the circulation of disease and the circulation of ideas," Wald (2008) stated, "...both displayed the power and danger of bodies in contact and demonstrated the simultaneous fragility and tenacity of social bonds" (p. 12). In other words, stories originate from the desire to comprehend pathological trajectories of bacteria and viruses. While epidemiologists strive to make communicable diseases "communicable" in the sense of phenomena that could be communicated and even controlled through scientific narrative patterns, fictional representations of disease may both utilize factual information and depart from it within the aesthetic domain. This departure is indeed inevitable in the sense that science, or medicine to be more specific, has never been and will never be able to answer all the crucial questions at once. Sufficient time and data is necessary to solve the mysteries, treatment and long-term impact of diseases. Besides, the affective dimension of plagues involving contemplation on human misfortune may be a low priority for objective research, "so we continue to speculate and construct plausible stories to render things more intelligible and less chaotic" (Healy, 2001, p. 9). The fruitful tension between fact and fiction thus makes what Wald (2008) called "the outbreak narrative" enduring in human imagination: stories about pandemics and infection "simultaneously forecast the imminent destruction and affirm the enduring foundations of community" (p. 10).

Outbreak narratives have expectedly gained prominence in the contemporary moment with the ongoing global debate on psychological, economic, and political challenges that exacerbate the course of the pandemic. Defoe's A Journal of the Plague Year (1722), which has been less popular than his 1719 classic Robinson Crusoe, is one of those works that have come to the foreground as people search for answers and try to develop a sense of stability through past experience. A Journal is the eyewitness account of an unnamed narrator who reveals his initials as H.F. at the end of the work. H.F. is a saddler residing in London during the Great Plague that devastated the city between 1664 and 1665. Defoe was five at the time, so even though he had lived through the pandemic himself, it could be safely assumed that the account is more of a fictional reconstruction than a testimony. He may have derived his account from the memories of his uncle Henry Foe, as indicated by the initials of the narrator, and synchronized what he heard with the experiences particular to London. The bubonic plague that broke out in Marseilles in 1720, however, seems to present a more relevant context for the author since he published A Journal two years after the outbreak, and he was then an established author who had recently published Robinson Crusoe (Keys, 1944, p. 52).

A Journal is not the only book that Defoe penned about the plague theme. Due Preparations for the Plague was released in the same year, complementing the former's mostly, if not completely, fictional content with its more philosophical and spiritual perspective. As Defoe elaborates on preparations against and for the plague, he also shares his (semi)scientific theories on the transmission of contagious diseases. Still, Due Preparations also utilizes fictional stories to deliver its own message. The main argument of this paper, that is, the idea that contagion could operate not only as a thematic thread but also as a method or medium also applies to the latter work as exemplified by Janette Turner Hospital's eponymous 2003 novel Due Preparations for the Plague (Mitchell, 2010, p. 53). The discussion here is, 
however, framed within A Journal and Ten Plagues to be able to explore the innovative narrative possibilities produced by the palimpsestic relationship between the main source and the adaptation especially when the two belong to different artistic realms such as a formally hybrid novel and a song cycle.

The explanatory writing on the title page of the first edition of $A$ Journal encapsulates both the content of the book and the stylistic choices of the author: "being observations or memorials of the most remarkable occurrences, as well public as private, which happened in London during the last great visitation in 1665 . Written by a Citizen who continued all the while in London. Never made public before" (1722/2001, p. 1). This citizen whom the reader discovers to be H.F. at the end decides to stay in the city unlike other-mostly- affluent people who have the means to leave the town, and depicts the pandemic horrors he encounters on the streets of London. Defoe juxtaposes H.F.'s observations with the poignant stories the latter has supposedly heard about the plague victims and survivors as well as with the cumulative reports quoted, and in some instances evaluated, by H.F. himself. Much of this data includes Defoe's reproductions of official documents such as mortality bills, medical reports, and public declarations. The whole text reflects a duality "between the anecdotal, subjective, and sympathetic account provided by the narrator... on the one hand, and the formal, objective, and cold records, purportedly hard facts, on the other" (Seager, 2008, p. 640). As the cases of infection and numbers of the deceased gradually increase, fears escalate, and strict measures are enforced by the authorities to maintain social order, a familiar pattern for all who have witnessed pandemics in the past and present.

A Journal is a book laden with epistemological tensions. The narrator describes the plague as a "formidable enemy ... armed with terrors that every man is not sufficiently fortified to resist or prepared to stand the shock against" (1722/2001, p. 223). There is limited, if not no, coherent and reliable information about the origins of the disease, and the narrator presents competing discourses in order to capture its source and impact. H.F shares how rumours, false treatments, and prophecies circulated in the city cause unrest and chaos: "The apprehensions of the people were likewise strangely increased by the error of the times; in which, I think, the people, from what principle I cannot imagine, were more addicted to prophecies and astrological conjurations, dreams, and old wives' tales" (1722/2001, p. 22.) He tells about men in delirium: "one in particular, who, like Jonah to Nineveh, cried in the streets, 'Yet forty days, and London shall be destroyed"' (1722/2001, p. 22). There is also a naked man running on the streets constantly wailing without saying anything else: "Oh, the great and the dreadful God!" (1722/2001, p. 22), which conveys the widely accepted belief that the plague, just like in the Bible, symbolizes divine vengeance and is sent by God to punish humanity for its evil ways. The direct references and allusions to the Prophet Jeremiah (1722/2001, p. 184) and the Book of Exodus with its plagues (1722/2001, p. 249) highlight the theological interpretation embraced by most Londoners and at times by the narrator too.

Similar to someone who would be cautious about the spread of fake news on old and new media in the twentieth century, H.F. strives to explain the situation in London as a distant objective observer while simultaneously commenting on the circumstances and the mindset of the people, and even assessing the accuracy of the data provided in the mortality bills. "If I may be allowed to give my opinion, by what I saw with my eyes and heard from other people that were eye-witnesses, I do verily believe," H.F. tells the reader, "that there died at least 100,000 of the plague only, besides other distempers and besides those ... who were not put down in the bills though they really belonged to the body of the inhabitants" (1722/2001, p. 95.) Despite missing information and mostly sensational or sentimental approaches to the pandemic, the narrator adheres to his didactic purpose throughout his account, which is to present

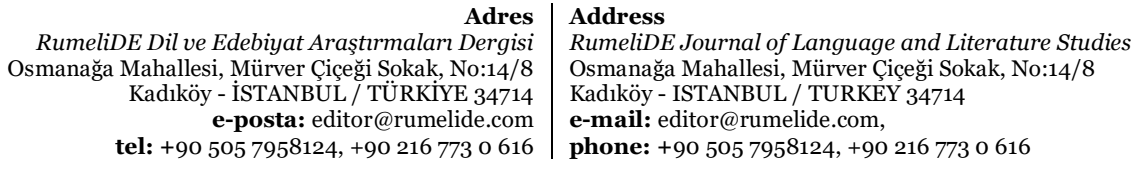


an accurate portrayal of events so that posterity can learn from both the wrong steps and right decisions. He repeatedly explains the measures taken against the plague in detail: houses are shut up and marked in the case of infection, and watchmen are appointed to enforce quarantine. Business is limited; theatres, public dancing-rooms and music houses, which according to the narrator "multiplied and began to debauch the manners of the people" (1722/2001, p. 29) are closed as people's minds are occupied by the fear of disease and death. A pest-house is built for the sick, and burials are conducted at specific times without the presence of friends and family. Defoe meticulously endeavour to inform the reader in a somewhat unified manner through a vast array of information. There is, however, still something about the plague that escapes representation. Even when he has the firsthand experience, he is unable to depict the extent of the calamity in some instances as demonstrated by his visit to a burial pit filled with dead bodies: “... it was indeed very, very, very dreadful, and such as no tongue can express" (1722/2001, p. 59). This "rhetoric of ineffability" (Seager, 2008, p. 647) or the failure to fully portray the dreads of the plague leads the author to resort to fiction and storification in addition to statistical data.

H.F. converses with people and includes their personal experiences in his report in order to portray their misery and the difficulties they encounter. He assigns a significant portion of his work to stories he has heard and remembered, if not fabricated, including that of two brothers and a relative, who with other people start a small community outside the towns they would like to pass through to escape infection in their own parish. According to Jennifer Cooke (2009), plague texts like Defoe's A Journal and Camus's The Stranger "suggest that fiction may be in a privileged position to address the trauma of enormous death counts, of fear of infection resulting from epidemic outbreaks and possibly even - hence rendering them still contemporarily relevant - other analogous historical events of mass destruction" (p. 17). A Journal particularly validates Cooke's point by stressing the indispensability of stories in an account that also aspires to be scientific and objective. Having declared his didactic purposes, Defoe's narrator justifies his use of stories by stating that especially poor people can find a pattern to follow "if ever such a time comes again; and if there was no other end in recording it, I think this a very just one, whether my account be exactly according to fact or not" (1722/2001, p. 117). These words imply that truth-value could be secondary if the stories serve their purpose of representing the plague not only as numbers but also as an emotionally charged, lived experience. Stories may operate to convey another form of truth that is equally relevant and significant.

To reconcile the general with the personal and particular is a challenging task for all authors. Defoe voices this challenge through H.F's commentary on the benefits of enforced quarantine for preventing death tolls from increasing. Still, as people have limited conversation with each other, "it was impossible any particular person could come at the knowledge of all the extraordinary cases that occurred in different families" (1722/2001, p. 156). The stories thus not only amplify the dramatic effect of the account and help to articulate what is at times inexpressible but also provide insight into particulars and diverse viewpoints as they reveal the incidents befalling different people. At one point, H. F. narrates the sad stories of two men, which function as metonymical representations of the pain and misery engulfing the whole town:

I could dwell a great while upon the calamities of this dreadful time, and go on to describe the objects that appeared among us every day, the dreadful extravagancies which the distraction of sick people drove them into; how the streets began now to be fuller of frightful objects, and families to be made even a terror to themselves. But after I have told you, as I have above, that one man, being tied in his bed, and finding no other way to deliver himself, set the bed on fire with his candle, which unhappily stood within his reach, and burnt himself in his bed; and how another, by the insufferable torment he bore, danced and sung naked in the streets, not knowing one ecstasy from another; I say, after I have mentioned these things, what can be added more? What can be said to represent the misery of

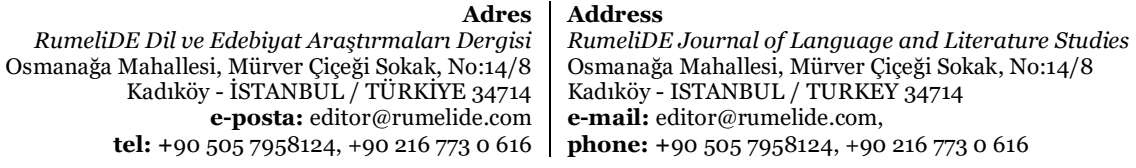


these times more lively to the reader, or to give him a more perfect idea of a complicated distress? (1722/2001, p. 168)

The numbers in the mortality bills and medical reports are of utmost importance to inform the public and maintain the order. However, as Defoe "moves away from a literal and absolute version of truth towards a fictional and representative one" embodied in such stories mentioned above, people gradually become more than just numbers; "Improbability is irrelevant, because the story "may serve to confirm the many' actual events that make up the plague year" (Seager, 2008, p. 651). Symptoms, infections, hardships; in short, the whole experience of and the dismal losses caused by the plague compressed into numerical figures in tables can now proliferate thanks to the narrative "plenitude" generated by the individual stories that "participate in and augment the overall plague account" (Cooke, 2009, p. 17).

\section{Adapting (to) the plague: Ten Plagues}

The idea of proliferation, verbal or viral, is reminiscent of the idea of contagion, and as both signify variety and change, they can in turn be associated with the idea of adaptation. In a similar vein, Wald (2008) observed that "the outbreak narrative is conventional and formulaic, but it is also always evolving. Stories of disease emergence in all their incarnations are so powerful because they are as dynamic as the populations and communities that they affect” (p. 28). Mark Ravenhill reflects this dynamism in the libretto of his 2011 Ten Plagues, which was first performed at the Traverse Theatre in Edinburgh Fringe Festival by Marc Almond. Ravenhill is one of the most critically acclaimed and accomplished contemporary playwrights of Britain, and his plays such as Shopping and $F^{* * * i n g ~(1996) ~}$ and Shoot/Get Treasure/Repeat (2008) have been widely performed in the UK and on the international stage. They have also received ample scholarly attention. Ten Plagues, however, is an arguably neglected yet equally remarkable work that communicates past and present anxieties gathering around plagues and their consequences.

While the physical space of theatre has been simultaneously threatened and considered a threat itself as one of the most infectious locations during epidemics as Defoe's narrator also underlines, plague and contagion as subject matter, motif or metaphor is actually germane to the narrative and performative dynamics of theatre. The two examples mentioned at the beginning of this paper, namely Oedipus Rex (ca. 429 BC) and The White Plague (1937) testify to this intricate link, and many more could be added to the list. Exploring what she called "theatre in/as/of epidemics," Maria Ristani (2020) drew attention to the ubiquity of the disease theme and imagery in theatre, which has various functions ranging from symbolically initiating the main action of the play to addressing the actual epidemics, scientific discourses, and governmental policies at the time. Ristani's survey refers to Shakespeare, Chekhov, Ibsen, and other playwrights who tackled the AIDS crisis in the last decades of the twentieth century. But perhaps one of the most intriguing critical interventions, as Ristani would also agree, came from Antonin Artaud in his 1933 essay "The Theatre and the Plague." Artaud established an organic link between the two:

The plague takes images that are dormant, a latent disorder, and suddenly extends them into the most extreme gestures; the theatre also takes gestures and pushes them as far as they will go: like the plague it reforges the chain between what is and what is not, between the virtuality of the possible and what already exists in materialized nature. ... In the true theatre a play disturbs the senses' repose, frees the repressed unconscious, incites a kind of virtual revolt (which moreover can have its full effect only if it remains virtual), and imposes on the assembled collectivity an attitude that is both difficult and heroic. (1933/ 1958, pp. 27-28)

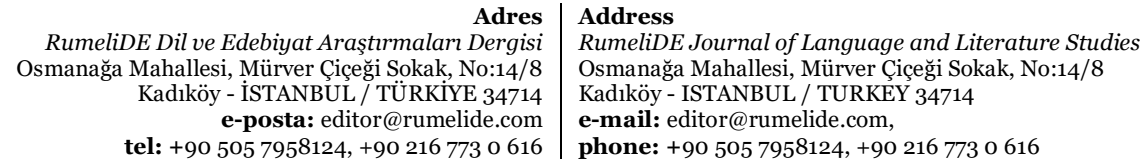


Artaud's analogy between the extremity of the plague and the provocative potential of theatre is compelling especially in its affirmative view on disease and faith in performative destruction of the status quo. This paper, however, takes its cue from a different type of relationship: the open-ended "dramaturgy of pestilence" (Gomel, 2000, p. 412) that manifests itself as textual and dramaturgical adaptation to the relatively less familiar form of the song cycle.

In the introduction to his libretto, Ravenhill wrote, "when I read Daniel Defoe's A Journal of the Plague Year I found my connection with the subject. Defoe's mercantile London felt close enough to my own world to allow a way in" (2013, p. xi). He also stated that he drew upon the writings of Samuel Pepys, Virginia Woolf and Susan Sontag on the pervasiveness of plagues and illnesses. To revisit the proposal of the paper that contagion could operate conveniently as a method or medium in plague narratives, Linda Hutcheon's understanding of adaptation as a palimpsest that both builds on and diverges from the source texts proves useful to interpret Defoe's and Ravenhill's plague-ridden texts. The two definitions of the word "palimpsest" as "writing material (such as a parchment or tablet) used one or more times after earlier writing has been erased" and "something having usually diverse layers or aspects apparent beneath the surface" indeed demonstrate the appropriateness of Hutcheon's formulation (Merriam-Webster, 2021). Similar to Wald's emphasis on evolution of stories (2008, p. 28), Hutcheon described adaptation as "a form of intertextuality: we experience adaptations (as adaptations) as palimpsests through our memory of other works that resonate through repetition with variation" (2006, p. 8). Adaptation is thus "process and product" at the same time, and it could be applied to much wider media than simply films and stage productions. Musical arrangements, visual artworks, and different forms of digital art could all be examples of adaptation (Hutcheon, 2006, p. 9). The interaction between repetition and difference expressed through various media necessitates the use of diverse techniques to produce an innovative adaptation. For this reason, adaptation is not only a palimpsest but also "a transcoding into a different set of conventions" (Hutcheon, 2006, p. 33). Ravenhill transcodes the hybrid narrative of Defoe into a cycle of fifteen songs through which he creates condensed images of the psychological devastation and social isolation inflicted by the plague on inhabitants of the city. "The solo voice and piano of a song cycle," Ravenhill explained in his introduction, "seemed right for this theme of solitude" (2013, p. xi). The mostly atonal melodies written by the composer Conor Mitchell to accompany Ravenhill's lyrics and Almond's powerful performance in fact amplify this sense of solitude and inner as well as outer turmoil.

The "deceptively simple libretto" (Gardner, 2011) of Ten Plagues mimics the first person narrative voice of A Journal. The "I" of the lyrics, however, seems to correspond to different characters without revealing their identities. Ravenhill envisions close-up (mental) shots of several people that may range from a merchant, a poor servant, and an officer to the deranged man running naked on the streets as also spotted previously by Defoe's narrator. The cycle opens with the stark contrast between the happy mood signified by the change of season and coming of the plague in the first song titled "Spring:"

The spring is here

I'll buy

A ring

To wear

The spring is here

A door in Drury Lane

Red cross

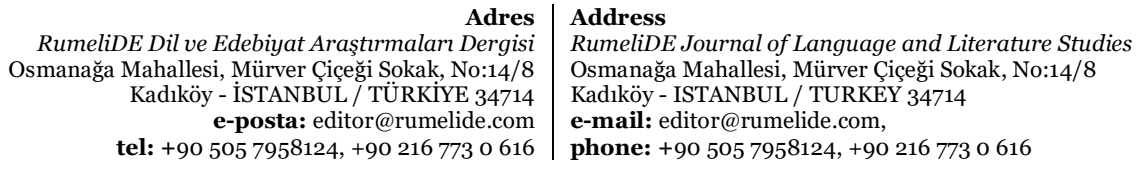


I want to buy a ring

The spring is here

A house shut up

The people say

May God preserve us

The spring is here (2011/2013, p. 363).

These brief and staccato lines signify a radical disruption in the sense of normalcy due to the plague, and effectively convey the speaker's confusion. "Without a Word," the title of another piece in the cycle, is also telling in this respect: "Suddenly/ I need a God," the character says, "But/ The pulpit is/ Empty/ The preacher fled/ There is no Word" (2011/2013, p. 364). The image of an empty pulpit could be interpreted both as the symbol of the scourge of God mentioned in H. F.'s account, and as the spiritual void felt by the person in the face of an impending doom. It also alludes to the impossibility of expressing the physical and emotional horrors of diseases and contagion, perhaps this time not from the perspective of the eyewitness but from that of someone who has the firsthand experience. The escape of the preacher upsets the speaker who wants to take his place to address the congregation, and the intended sermon reveals the extent of the crisis. The speaker wants to preach that "The King has fled/ And courtiers/ The palace empty/ There is no rule" (2011/2013, p. 364). The plague has caused not only spiritual but also socio-political anxiety with the accompanying fear of chaos and anarchy.

In "Farewell," Ravenhill heightens the sense of solitude through the image of an impossible kiss between two characters -most probably lovers-, which is again highly relatable both in the time of the bubonic plague depicted by Defoe and in the quarantined world of the Covid pandemic. Upon seeing the tumour of the lover, the speaker feels agitated and yet saddened by the necessity of keeping distance: "This is my last days/ You said/ And so goodbye/ I was frightened/ That you'd kiss me/ I could have hit you/ For bringing your infection/ Here." Instead of hitting the lover, however, the speaker stands apart and says goodbye because "The time to kiss is over" (2011/2013, p. 370). At this point, Almond's solo performance on stage is supported by video installations that reflect a male figure as the lover, which could be interpreted as Ravenhill's dramaturgical gesture towards the global HIV/AIDS epidemic, that is, as the playwright's endeavour to understand Defoe's plague within more recent contexts. That he listed Sontag as a source of inspiration in his introduction to the libretto seems to support this interpretation although there are no explicit references to AIDS in the play. Sontag's comment that "plague' is the principal metaphor by which the AIDS epidemic is understood" (1989, p. 44) is relevant both to the title and to the staging, if not the content, of the adaptation.

The strongest articulation of the emotional damage caused by the plague is arguably in the lyrics of "Grief." This time imitating the voice of Defoe's H.F., the speaker shares the story of a mother who has lost her daughter to the plague. They also pay a visit to the burial pits, which in Defoe's story has rendered the narrator speechless. Yet, something else is troubling the speaker in Ravenhill's version. People seem to be desensitized to this horror and pain, perhaps because they fail to fathom the extent of it and confront their own losses. The speaker laments that "We all are plagued/ Our hearts are gone/ Our bodies live/ We walking dead/ About the city now" (2011/2013, p. 381). Any disease, especially when large-scale, is a transformative experience, and Ravenhill's zombie metaphor is fitting inasmuch as it pertains to the shared sense of devastation and lifelessness following pandemics throughout history. Nevertheless, life and human resilience should and does prevail as promoted at the end of both works. Defoe's H.F. closes his account with a brief poem not unlike those of Ravenhill: "A dreadful plague in

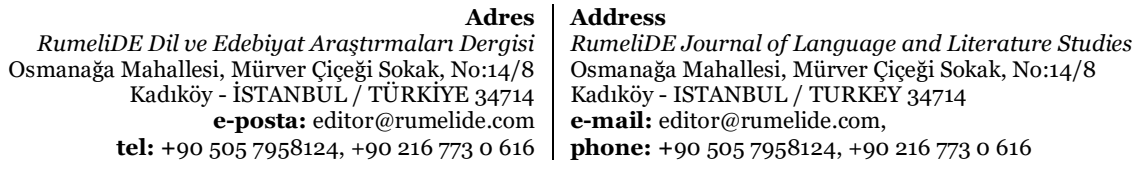


London was/ In the year sixty-five/ Which swept an hundred thousand soul/ Away; yet I alive!" (1722/2001, p. 236). Drawing upon the biblical story of the Ten Plagues, Ravenhill also completes the cycle with the idea of survival. In the eponymous song, the speaker says, "Now/ We never talk/ Of plague/ We live/ We push our memory down/ And live/ Learn the new dance/ Sing the new song." The following lines, however, seem to insinuate the imminence of different threats for humanity: "The shops fill/ A new war/ We live" (2013, p. 386). In his Epilogue, he echoes the cautious yet resilient tone of Defoe's narrator: "In London/ Came the plague in sixteen sixty-five/ One hundred thousand dead/ But I alive" (2013, p. 386).

\section{Conclusion}

As Ravenhill's speaker has also observed in the song entitled "Ten Plagues," humanity has no chance but to learn the new dance and sing the new songs in order to survive and recover from traumatic experiences such as epidemics. However, new threats and plagues, which can never be considered simply and only as health issues as they are intrinsically linked with wider political, economic and ecological circumstances, may always be awaiting around the corner with similarly devastating consequences as Ravenhill's song “Ten Plagues” implies. The outbreak of Coronavirus disease, as well as of past predecessors such as SARS, H1N1, avian influenza, Ebola, and Zika virus, is in fact the best example of this entangled situation. In this respect, although Girard correctly underlined the prominence of the plague as a major metaphor in literature for social deterioration, he has been proven wrong in his statement that "the plague and epidemics in general have disappeared almost altogether" (1974, p. 835). David Steel's point is likewise both valid and false: "despite the rarity of outbreaks today contemporary literature bears witness to the continuing vitality of its symbolic possibilities" (Steel, 1981, as cited in Cooke, 2009, p. 8). Outbreaks are not rare, but literature indeed bears witness to diseases, infection, loss, grief, and possibilities of survival.

This paper has engaged with one of the ways literature could intervene in the dialogue around the representation of the plague, arguing that contagion could be considered a convenient methodical tool that foregrounds both the thematic specificities and formal open-endedness of plague narratives. The interpretative layers of the two works examined, Defoe's A Journal of the Plague Year (1722) and Ravenhill's song cycle Ten Plagues (2011), an adaptation of the former, (co)create an aesthetic space, or as the word "contagion" suggests, touch together and present the horrors of the plague in its "impossible" totality. While Defoe focuses on the lessons he can teach posterity through his narrator, Ravenhill highlights the fragility of human psyche and its unpreparedness for diseases and outbreaks. His innovative adaptation complements Defoe's account by shifting narrative perspectives, condensing the emotional experience of the plague in different characters, and re-contextualizing the bubonic plague within more recent epidemics. Defoe and Ravenhill attempt to establish the power of art and fiction in responding to isolation and connection, or despair and hope in dire times, and lead their audience to contemplate on diseased pasts and futures through the palimpsestic interactions between texts and plagues.

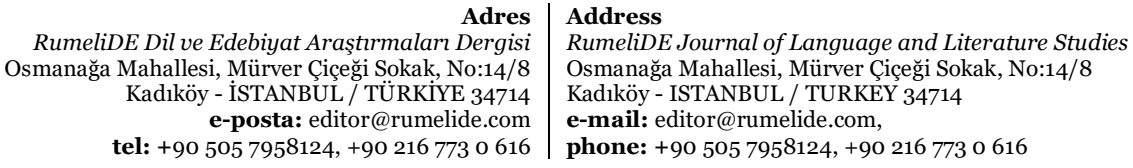




\section{References}

Artaud, A. (1958). The theatre and its double. Grove Press. (Original work presented in 1933).

Cooke, J. (2009). Legacies of plague in literature, theory and film. Palgrave Macmillan.

Defoe, D. (2001). A Journal of the plague year. The Modern Library Paperback Edition. (Original work published in 1722).

DeWall, N. (2011). Sweet recreation barred": The case for playgoing in plague-time. In R. Totaro and E. B. Gilman (Eds.), Representing the plague in early modern England, 133-149. Routledge.

Gardner, L. (2011, Aug 8). Ten Plagues- Review. The Guardian. Retrieved August 9, 2021, from https://www.theguardian.com/culture/2011/aug/o8/ten-plagues-edinburgh-almond-review

Girard. R. (1974). The plague in literature and myth. Texas Studies in Literature and Language, 15 (5), 833-850.

Gomel, E. (2000). The plague of utopias: Pestilence and the apocalyptic body. Twentieth Century Literature, 46 (4), 405-433. http://www.jstor.org/stable/827840.

Hays, J. N. (2009). The burdens of disease: Epidemics and human response in western history ( $2^{\text {nd }}$ ed.). Rutgers University Press.

Healy, M. (2001). Fictions of disease in early modern England: Bodies, plagues and politics. Palgrave.

Homer (2015). The Iliad (P. Green, Trans.). California University Press. (Original work composed ca. $8^{\text {th }}$ century $\left.\mathrm{BC}\right)$.

Hutcheon, L. (2006). A theory of adaptation. Routledge.

Keys, Thomas E. (1944). The plague in literature. Bulletin of the Medical Library Association, 32, 3556. europepmc.org/backend/ptpmcrender.fcgi?accid=PMC194297\&blobtype=pdf.

Merriam-Webster. (n.d.). Palimpsest. In Merriam-Webster.com dictionary. Retrieved August 9, 2021, from https://www.merriam webster.com/dictionary/palimpsest

Mitchell, P. (2012). Contagious metaphor. Bloomsbury.

Outka, E. (2019). Viral modernism: The influenza pandemic and interwar literature. Columbia University Press.

Ravenhill, Mark (2013). Plays 3: Shoot/Get Treasure/Repeat; Over There; A Life in Three Acts; Ten Plagues; Ghost Story; The Experiment. Bloomsbury.

Ristani, M. (2020). Theatre and epidemics: An age-old link. Critical Stages. Retrieved August 9, 2021, from https://www.critical-stages.org/21/theatre-and-epidemics-an-age-old-link/?

Seager, N. (2008). Lies, damned lies, and statistics: Epistemology and fiction in Defoe's A Journal of the Plague Year. The Modern Language Review, 103 (3), 639-653. https://www.jstor.org/stable/20467902

Slack, P. (1992). Introduction. In T. Ranger and P. Slack (Eds.), Epidemics and ideas: Essays on the historical perception of pestilence, 1-20. Cambridge University Press.

Sontag, S. (1989). AIDS and its metaphors. Farrar, Straus, Giroux.

Tunbridge, L. (2010). Cambridge introductions to Music. Cambridge University Press.

Wald, P. (2008). Contagious: Cultures, carriers, and the outbreak narrative. Duke University Press.

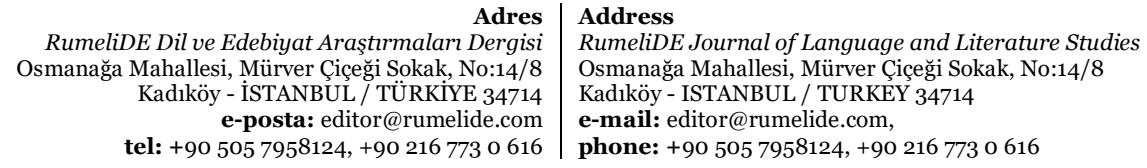

